\title{
ENDOCARP MORPHOLOGY OF AFRICAN CELTIS (CELTIDACEAE/ULMACEAE)
}

\author{
A. SATTARIAN \& L.J.G. VAN DER MAESEN \\ Nationaal Herbarium Nederland, Wageningen University branch (Herbarium Vadense), \\ Generaal Foulkesweg 37, 6703 BL Wageningen, The Netherlands; \\ e-mail: Ali.Sattarian@wur.nl
}

\section{SUMMARY}

Endocarp morphology of 14 species of mainly African Celtis was examined using light and scanning electron microscopy. Macro- and micro-morphological characters included endocarp shape, colour, size, surrounding rim and SEM examination of the outer layer of the endocarp. Different classes of shape and sculpture were recognised. A key for the identification of the investigated taxa based on endocarp characters is provided.

Key words: Celtis, Africa, endocarp, sculpture, shape.

\section{INTRODUCTION}

Celtidaceae (formerly Ulmaceae-Celtidoideae) (Elias, 1970; Grudzinskaya, 1976; Omori \& Terabayashi, 1993; Judd et al., 1994; Ueda et al., 1997) comprise c. 150 species classified in 9 genera, distributed in the Northern Hemisphere and in Africa, up to southern Africa. Some species of the family are ornamental; some are used for timber and reforestation.

In the flora of Africa, Celtidaceae is a small family with the main genus Celtis, at present represented by 12 species. The habitat of Celtis species reaches from North Africa (Algeria, Libya and Morocco) to South Africa and Madagascar. Several tree species are found in the rain forest (Celtis tessmannii Rendle, C. mildbraedii Engl.) or in semi-deciduous forest (Celtis adolfi-friderici Engl., C. prantlii Engl., C. zenkeri Engl.). Other Celtis species are shrubs or small trees of rain forest undergrowth (C. gomphophylla Baker), or found on the forest/savannah boundary, sometimes in montane forest (C. africana Burm.f.). One species (C.toka Forssk.) is a fairly large tree with a compact crown, living beside streams or planted in villages in the Sudano-Sahelian zone.

The fruits in Ulmaceae and Celtidaceae families are of two general types: dry and variously winged samaras or fleshy drupes. A wide variety of dry winged fruits occurs in the Ulmaceae and, along with endocarp features, are useful in distinguishing genera. Endocarps in the Ulmaceae are generally thin and soft except for Zelkova and Hemiptelea. Drupes characterize all genera of the Celtidaceae except for Pteroceltis, which has a winged drupe. Size ranges from approximately 1-2 $\mathrm{mm}$ in diameter in Lozanella, Parasponia, and Trema to up to $23 \mathrm{~mm}$ broad in Ampelocera glabra. Endocarps in the Celtidaceae are usually globose (except for Ampelocera, which can be ellipsoid, and Gironniera and Lozanella, which are lenticular), thick-walled and hard 
due to calcium carbonate in Celtis and sclereids in Aphananthe (Manchester, 1989). Reticulate surface sculpturing is found in Celtis, Peteroceltis, Trema, and Parasponia. Pteroceltis has spherical endocarps very similar to Celtis except for a pair of prominent rounded wings.

The cotyledons are usually folded in the Celtidaceae. Celtis is distinguished by its broad contorted cotyledons (Killip \& Morton, 1931). Seed coat (testa) features vary among the genera. Celtis, Chaetachme, and Pteroceltis have the most elaborate seed surface sculpturing in the family with many holes. Lozanella, Parasponia, and Trema have a lineate seed coat surface (Takaso \& Tobe, 1990).

The drupaceous fruits of the Celtidaceae vary in colour from bright yellow to orange, deep red, and purple and are primarily bird-dispersed. Celtis philippensis var. wightii, which grows in coastal forests in Melanesia, has been suggested to be water-dispersed (Soepadmo, 1977).

Most systematists agree that data concerning the macro- and microstructure of fruits and seeds are very significant for the classification of Angiosperm taxa. Heywood (1971) drew attention to the importance and impact of scanning electron microscopic (SEM) imaging in the study of systematic problems, as very valuable information has been provided by this technique. During the last decades, scholars have applied scanning electron microscopy to morphological studies of seeds and small fruits. Micro morphology and ultra-structural data have contributed useful information for evolution and classification of seed and fruit plants and play an important role in the modern synthetic systems of Angiosperms.

Most of the following studies focused on intrageneric seed coat variation in various structures (see Aniszewski et al., 2001); for the colours of seeds refer to Dahlgren \& Clifford (1982). In Celtidaceae, external seed morphology and germination were studied by Metcalfe \& Chalk (1950), Polhill (1964), Whiffin \& Tomb (1972), Corner (1976), Canne (1980), and Barthlott (1981). These studies were focused on germination, extraction, nursery practice, germinative energy, and germinative capacity, while investigations on seed and not so much on endocarp morphology, and sculpture of endocarp are lacking. The present study set out to fill some of the gaps in our knowledge, focusing on the micro- and macro-morphological (Binocular and SEM) characters of endocarp of (mainly) African Celtis spp. to decide on the importance of endocarp characters as a criterion for separating species within this genus.

\section{MATERIAL AND METHODS}

Most of the endocarp material was taken from herbarium vouchers, especially from the herbarium at Wageningen (WAG), but also from sheets on loan from other herbaria (B, BR, K, L, P, W), see Table 1.

In general endocarps of Celtis can be inspected easily. Mature fruits were taken from the specimens, as far as available. The dried fruits were boiled in water for $10 \mathrm{~min}$. and brushed clean, then rinsed in water with bleach for $10 \mathrm{~min}$. to obtain clean endocarps. These were first examined by binocular (B) or light microscope (LM). Subsequently endocarps were mounted on stubs with double adhesive tape. The stubs were sputtercoated with gold-palladium for $2-3 \mathrm{~min}$. in a Polaron Equipment Ltd. SEM coating unit E5100. After coating, the specimens were examined with a Joel 5200 scanning electron 
Table 1. List of specimens used in (B/SEM) endocarp studies. $\mathrm{B}=$ binocular, $\mathrm{SEM}=$ electron microscope.

\begin{tabular}{|c|c|c|}
\hline Taxon & Collector & Country of origin \\
\hline C. adolfi-friederici Engl. & Mildbraed 825 & Cameroon $(\mathrm{K})$ \\
\hline C. africana Burm.f. & Dahlstrand 579 & South Africa (C) \\
\hline C. australiensis Sattarian & Chesterfield, E.A. 389 & Australia (L, PERTH) \\
\hline C. australis $\mathrm{L}$. & Sattarian 03BG15801 & Italy (Bot. Gdn WAG) \\
\hline C. bifida Leroy & O'Connor 44 & Madagascar (K) \\
\hline C. gomphophylla Baker & Chapman 9361 & Malawi (MO) \\
\hline C. malagasica Sattarian & Phillip, P.B. 2938 & Madagascar (MO) \\
\hline C. mildbraedii Engl. & Leeuwenberg 4078 & Ivory Coast (WAG) \\
\hline C. philippensis Blanco & Soepadmo 7225 & Malaysia (L) \\
\hline C. prantlii Priemer ex Engl. & Le Testu 1479 & Gabon (WAG, P) \\
\hline C. tessmannii Rendle & Liben 2254 & D.R. Congo (BM) \\
\hline C. toka Forssk. & De Wilde, W.J.J.O. 5287 & Cameroon (WAG) \\
\hline C. wightii Planch. & Ludanga 782 & Tanzania (C) \\
\hline C. zenkeri Engl. & Leeuwenberg 6227 & Cameroon (WAG) \\
\hline
\end{tabular}

microscope. All photomicrographs were taken at the Department of Plant Cytology and Morphology, SEM Laboratory, Wageningen University, The Netherlands.

\section{RESULTS}

Endocarp characters prove to be important to distinguish species of African Celtis in Ulmaceae/Celtidaceae. The endocarp shape varies from elliptic to ovoid, lenticular, or ovoid-beaked. The size of the endocarp ranges from small ( 4 by 3 by $2 \mathrm{~mm}$ ) to large (11 by 10 by $8 \mathrm{~mm}$ ) and is very useful in terms of identification of species. The endocarp colour varies from white, cream, and grey to brown and helps to separate species. The endocarp shape varies from globular to polygonal. The outer layers of the endocarp differ; they curve and are raised from the bottom to the top but in different directions. The apex of the endocarp is round or beaked. The ridges of the endocarp are another character; from a faint ridge to 1-3 clear ridges can be seen among African Celtis. Outer layers of the endocarp (sculpture) vary from smooth with different size of holes, to a prominent rough surface, and membranous platelets can be present. The ratio of $\mathrm{D} / \mathrm{L}$ endocarp length also varies from $3 / 4$ to $6 / 8$, for more details of the species see Table 2 .

\section{ENDOCARP CHARACTERS}

\section{Endocarp shape}

The shape of the endocarp showed variation among the African Celtis. Most of the endocarps vary from ovoid-acuminate to ovoid. They are ovoid-acuminate in C. australis, C. bifida, C. philippensis, C. prantlii, C. toka, C. wightii, and C. zenkeri (Table 2), lenticular-ovoid in C. africana and C. tessmannii, angular-ovoid in C. gomphophylla, and globose to ellipsoid in $C$. adolfi-friederici. 


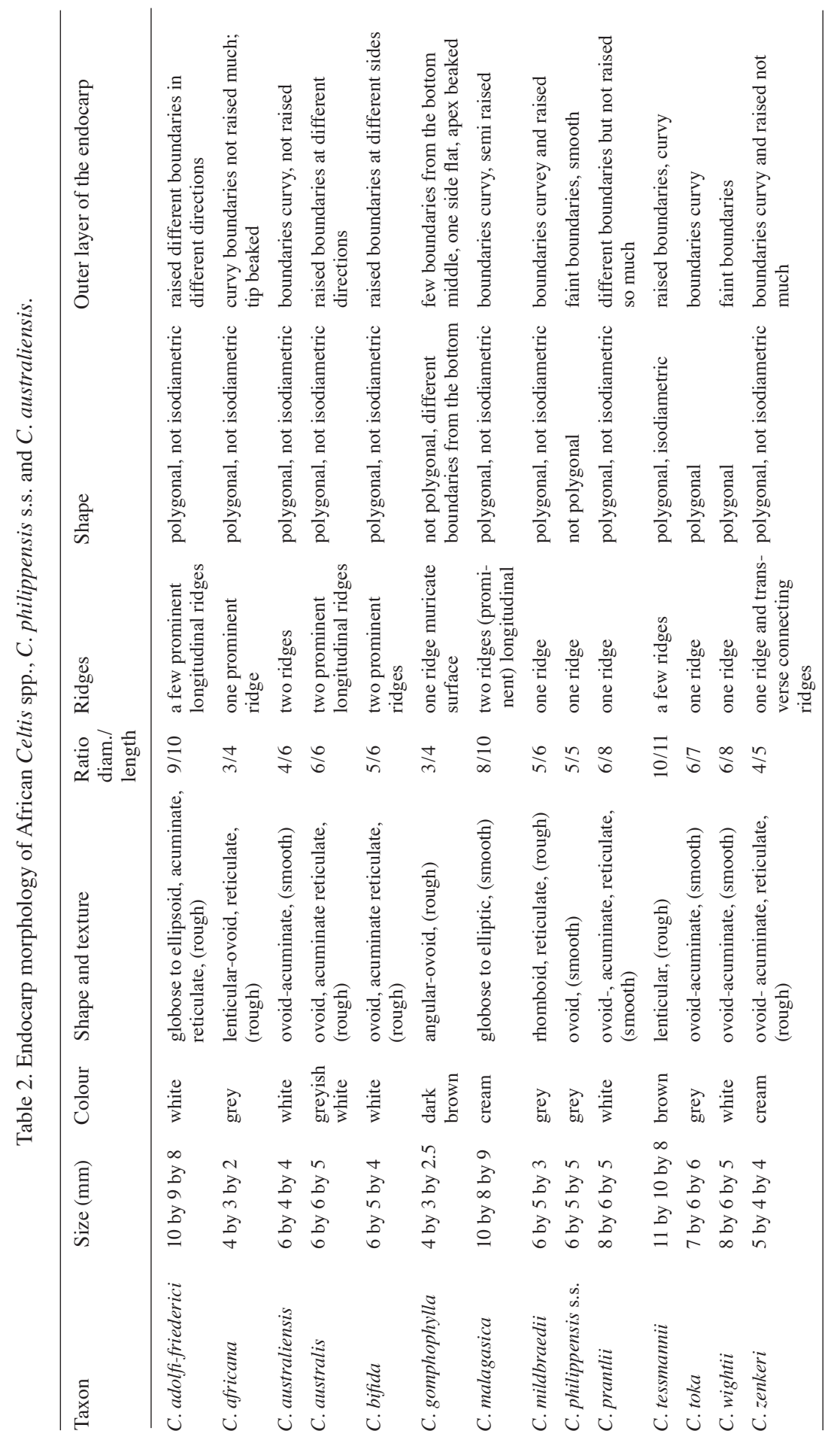


Two classes of endocarp epidermis surface can be distinguished: smooth and rough. Celtis philippensis has a smooth epidermis, and C. adolfi-friederici, C. africana, C. bifida, C. gomphophylla, C. mildbraedii, C. tessmannii, and C. zenkeri have a rough epidermis.

\section{Endocarp size}

The size of the endocarp also varies. The range is from the smallest one ( 4 by 3 by $2 \mathrm{~mm}$ ) in C. gomphophylla and C. africana to the largest one (11 by 10 by $8 \mathrm{~mm}$ ) in C. tessmannii, but the majority of the endocarps measure about 6 by 5 by $5 \mathrm{~mm}$ in C. australis, $C$. bifida, C. mildbraedii, C. philippensis, $C$. toka, $C$. wightii, and $C$. zenkeri.

The endocarp size is a good character, useful to separate $C$. adolfi-friederici and C. tessmannii from the rest of African Celtis.

\section{Endocarp colour}

The colours of the endocarp are diagnostic and of systematic interest among African Celtis. A white endocarp is seen in C. adolfi-friederici, C. bifida, C. prantlii, and C. wightii, while a grey colour is seen in C. africana, C. australis, and C. mildbraedii. Celtis gomphophylla has a dark brown endocarp; it is light brown in C. tessmannii, while $C$. zenkeri has a cream-coloured endocarp.

\section{Ridges}

The presence/absence of a ridge on the endocarp is a significant character in African Celtis. There are no ridges in C. philippensis, there is one main ridge in C. africana, C. gomphophylla, C. mildbraedii, C. prantlii, C. toka, C. zenkeri, C. wightii and a few ridges can be seen in $C$. tessmannii and $C$. adolfi-friederici (Table 2).

\section{Endocarp sculpture (ornamentation)}

African Celtis species often have a polygonal sculpture. This structure is formed by the ridges and cross-connection between the edges. Polygonal sculpture is found in C. adolfi-friederici, C. africana, C. australis, C. bifida, C. mildbraedii, C. tessmannii, and $C$. toka, and normally the surface is rough, especially in $C$. tessmannii and C. adolfi-friederici, and the polygons are curved. A non-polygonal shape is found in C. gomphophylla, but there are some prominent edges from the bottom. Celtis philippensis has also a non-polygonal shape and smooth surface.

Table 3. Description of endocarp surface (shape of outer layer of the endocarp) of selected species (SEM photographs).

\begin{tabular}{ll}
\hline Taxon & Description SEM \\
\hline C. adolfi-friederici & $\begin{array}{l}\text { Rough layers with different size of holes, prominent surface sculpturing, } \\
\text { membranous platelets present }\end{array}$ \\
C. africana & $\begin{array}{l}\text { Smooth layers and fissured layers } \\
\text { C. australis }\end{array}$ \\
C. mildbraedii & $\begin{array}{l}\text { Rough surface, with a few holes, membranous platelets present } \\
\text { Smooth layers and crusts, continuous coverings usually without very } \\
\text { prominent surface }\end{array}$ \\
C.tessmannii & $\begin{array}{l}\text { Rough layers with holes, prominent surface sculpturing, membranous } \\
\text { platelets present }\end{array}$ \\
C. wightii & Rough layers with different holes, prominent surface sculpturing \\
\hline
\end{tabular}



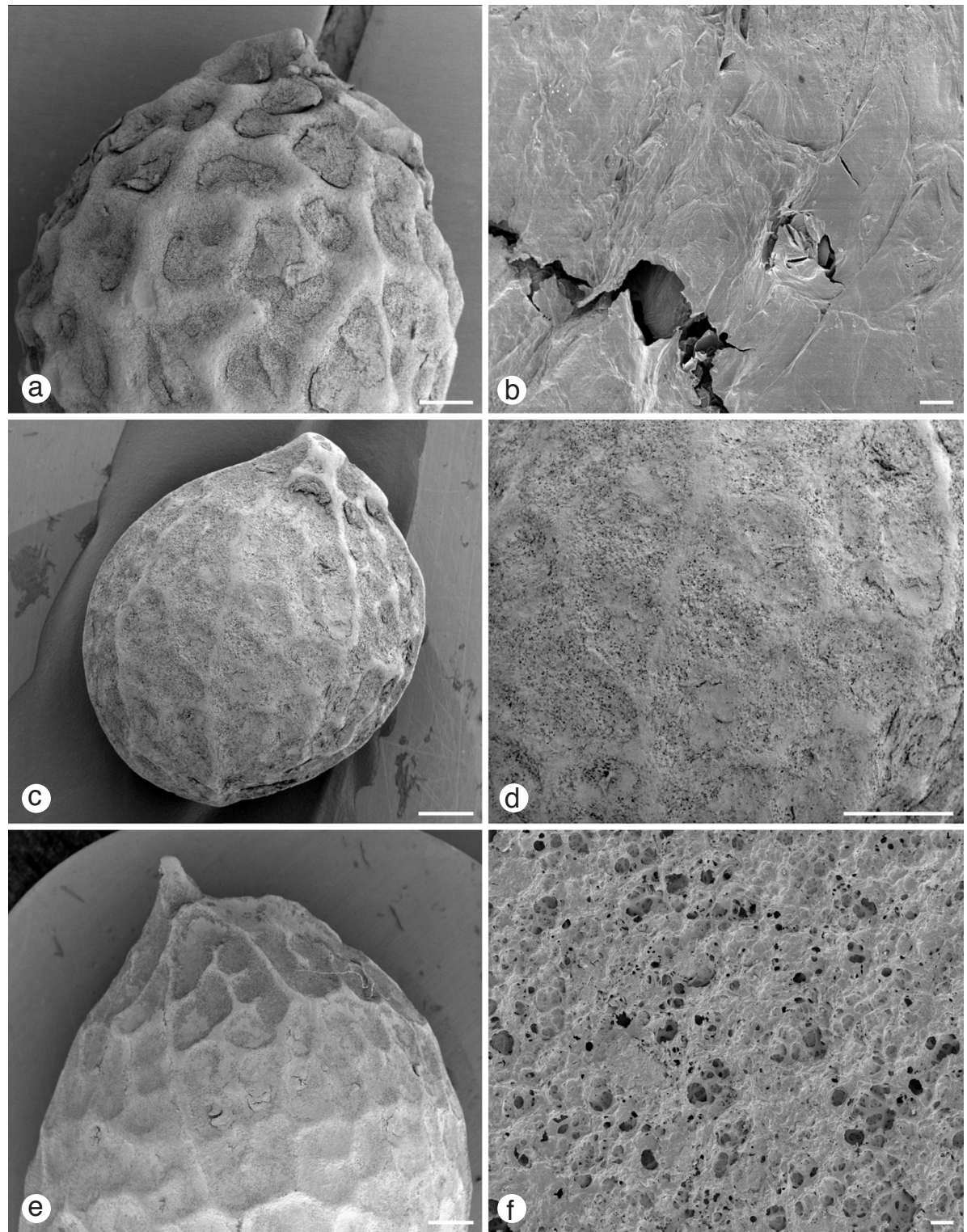

Plate 1. SEM micrographs of Celtis species. a, b. C. adolfi-friederici Engl.; c, d. C. australis L.; e, f. C. tessmannii Rendle. - Scale bars: a, c, e $=1 \mathrm{~mm}$; b, d, f $=10 \mu \mathrm{m}$. 

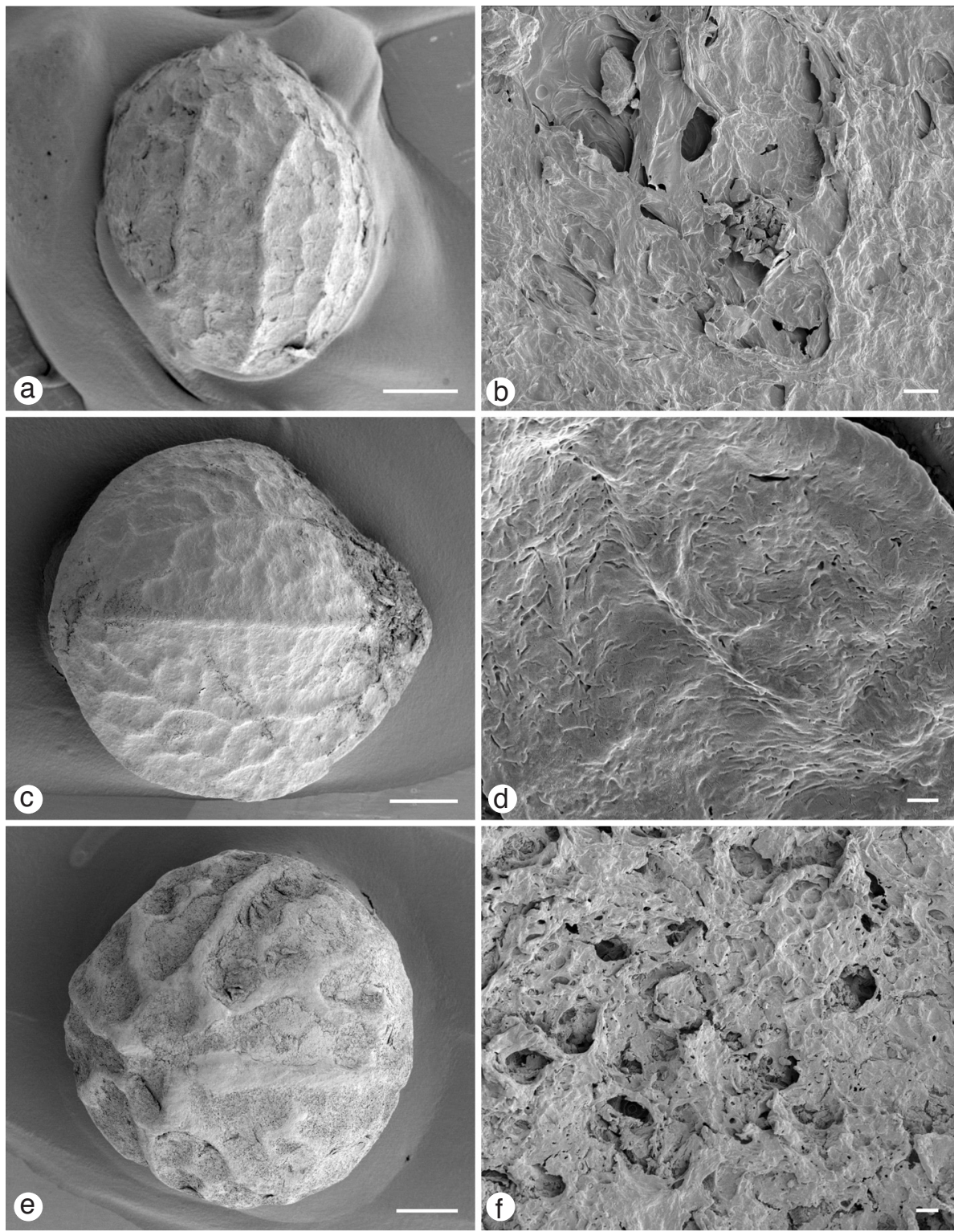

Plate 2. SEM micrographs of Celtis species. a, b. C. africana Burm.f.; c, d. C. mildbraedii Engl.; e, f. C. wightii Planch. - Scale bars: a, c, e $=1 \mathrm{~mm} ; \mathrm{b}, \mathrm{f}=10 \mu \mathrm{m} ; \mathrm{d}=1 \mu \mathrm{m}$. 
In some species the apex is conspicuously pitted: in C. adolfi-friederici, C. gomphophylla, and C. tessmannii (Plate 1,2).

With high magnification the outer walls of the endocarp or periclinal walls can be seen to differ. There are two main types. One type of endocarp has rough layers with different sizes of holes, prominent sculpturing, and membranous platelets, while the other one is smooth-layered and fissured, it looks like films in different layers, smooth layers and crusts, and the coverings are usually continuous without very prominent surface sculpturing (Table 3).

\section{KEY TO AFRICAN AND SOME OTHER CELTIS SPECIES BASED ON ENDOCARP CHARACTERS}

1a. Endocarp angular-ovoid, dark brown. . . . . . . . C. gomphophylla

b. Endocarp ovoid-acuminate, lenticular or globose, other colours. . . . . . . . 2

2a. Endocarp lenticular-ovoid or rhomboid, reticulate $\ldots \ldots \ldots \ldots \ldots \ldots$

b. Endocarp ovoid-acuminate, globose, reticulate or smooth . . . . . . . . 3

3a. Endocarp ovoid, reticulate, smooth or semi rough, various colours . . . . . . 4

b. Endocarp globose to elliptic, quite rough and sunken and raised reticular, white $\ldots \ldots \ldots \ldots \ldots \ldots \ldots \ldots \ldots \ldots \ldots \ldots \ldots \ldots \ldots \ldots \ldots$. adolfi-friederici

4a. Endocarp smooth, white or cream ................ 5

b. Endocarp reticulate with raised boundaries or lines, grey $\ldots \ldots \ldots \ldots \ldots 8$

5a. Endocarp smooth, hardly a few boundaries visible, apex rounded . . . . . 6

b. Endocarp more or less smooth, apex beaked $\ldots \ldots \ldots \ldots \ldots \ldots \ldots$

6a. Endocarp with a few boundaries, these not raised ......... malagasica

b. Endocarp without boundaries $\ldots \ldots \ldots \ldots \ldots \ldots \ldots \ldots$. philippensis

7a. Endocarp more or less smooth, apex rounded $\ldots \ldots \ldots \ldots \ldots$. prantlii

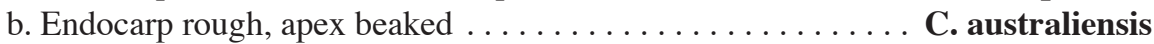

8a. Endocarp with raised lines and boundaries . . . . . . . . . . . 9

b. Endocarp polygonal, without raised lines . . . . . . . . . . . . . . . . . 10

9a. Endocarp grey . . . . . . . . . . . . . . . . . . . . . . . C. toka

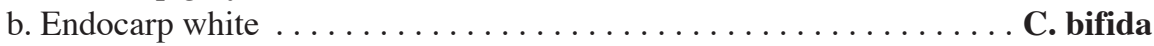

10a. Endocarp sunken polygonal $\ldots \ldots \ldots \ldots \ldots \ldots \ldots \ldots \ldots \ldots \ldots \ldots$. wightii

b. Endocarp raised polygonal $\ldots \ldots \ldots \ldots \ldots \ldots \ldots \ldots \ldots \ldots \ldots \ldots$

11a. Endocarp white, 6 by 6 by $5 \mathrm{~mm} \ldots \ldots \ldots \ldots \ldots \ldots$. australis

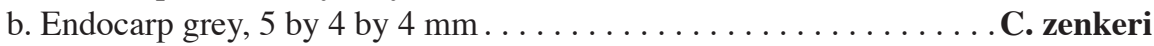

12a. Endocarp two-sided . . . . . . . . . . . . . . . . . . . . . 13

b. Endocarp four-sided $\ldots \ldots \ldots \ldots \ldots \ldots \ldots \ldots \ldots$. mildbraedii

13a. Endocarp more than $10 \mathrm{~mm}$ long, brown, apex beaked . . . . . C. tessmannii

b. Endocarp less than $10 \mathrm{~mm}$ long, grey, apex rounded ........ C. africana

\section{ACKNOWLEDGEMENTS}

We are grateful for the assistance of Dr. T. Heijerman, who took the photographs of the endocarps, and Mr. W.J. van der Burg for help with the key. 


\section{REFERENCES}

Aniszewski, T., K.H. Mervi \& A.J. Leinonen. 2001. Seed number, seed size and seed diversity in Washington lupin (Lupinus polyphyllus Lindl.). Ann. Bot. 87: 77-82.

Barthlott, W. 1981. Epidermal and seed surface characters of plant systematic applicability and some evolutionary aspects. Nordic J. Bot. 1: 345-355.

Dahlgren, R.M \& H.T. Clifford. 1982. The Monocotyledons. Academic Press, London.

Canne, J.M. 1980. Seed surface features in Aureolaria, Brachystigma, Tomanthera and certain South America Agalinis (Scrophulariaceae). Syst. Bot. 5: 241-452.

Corner, E.J.H. 1976. The seeds of Dicotyledons. Cambridge University Press, Cambridge.

Elias, T.S. 1970. The genera of Ulmaceae in the Southern United States. J. Arnold Arbor. 51: $18-40$.

Grudzinskaya, I.A. 1967. Ulmaceae and reasons for distinguishing Celtidaceae as a separate family Celtidaceae Link. Bot. Zhurn. 52: 1723-1748 (in Russian with English summary).

Heywood, V.H. 1971. Scanning electron microscopy. Systematic and evolutionary application. London.

Judd, W.S., R.W. Sander \& M.J. Donoghue. 1994. Angiosperm family pairs: Preliminary cladistic analyses. Harvard Pap. Bot. 5: 1-51.

Killip, E.P. \& C.V. Morton. 1931. The genus Lozanella. J. Wash. Acad. Sci. 21, 14: 336-339.

Manchester, S.R. 1989. Systematic and fossil history of the Ulmaceae. In: P.R. Crane \& S. Blackmore (eds.), Evolution, systematics, and fossil history of the Hamamelidaceae, Vol. 2: 221-251. Oxford, Clarendon Press.

Metcalfe, C.R. \& L. Chalk. 1950. Anatomy of Dicotyledons. Vol. 1. Oxford.

Omori, Y. \& S. Terabayashi. 1993. Gynoecial vascular anatomy and its systematic implications in Celtidaceae and Ulmaceae (Urticales). J. Pl. Res. 106: 249-258.

Polhill, R.M. 1964. Enumeration of the Ulmaceae in Africa South of Sahara. Kew Bull. 19: 139-145.

Soepadmo, E. 1977. Ulmaceae. Flora Malesiana 8, 2: 31-76.

Takaso, T. \& H. Tobe. 1990. Seed coat morphology and evolution in Celtidaceae and Ulmaceae (Urticales). Bot. Mag. (Tokyo) 103: 25-41.

Ueda, K., K. Kosuge \& H. Tobe. 1997. A molecular phylogeny of Celtidaceae and Ulmaceae (Urticales) based on rbcL. J. Pl. Res. 110: 171-178.

Whiffin, T. \& A. Tomb. 1972. The systematic significance of seed morphology in the neotropical capsular-fruited Melastomataceae. Amer. J. Bot. 59: 411-422. 